\title{
ATOMERŐMÛ́I BÓRKARBID SZABÁLYZÓ RÚD ROBBANTÁSOS PORTÖMÖRÍTÉSI TECHNOLÓGIÁJA
}

\section{EXPLOSIVE POWDER COMPACTING TECHNOLOGY OF NUCLEAR POWER PLANT'S BORON-CARBIDE REGULATOR ROD}

\author{
Borbély László ${ }^{1}$, Rácz Pál ${ }^{2}$ \\ Óbudai Egyetem, Bánki Donát Gépész és Biztonságtechnikai Mérnöki Kar, Anyag- \\ és Gyártástechnológiai Intézet, Cím: 1038 Magyarország, Budapest, Népszínház \\ utca 8; Telefon: +36-1-6665430, \\ Ilborbely11@gmail.com \\ ${ }^{2}$ racz.pal@bgk.uni-obuda.hu
}

\begin{abstract}
There are several methods can be used for producing regulator rods of nuclear power plants. Due to the small number of rods to be produced, the production process could be very costly, therefore not only the quality requirements but the production costs have to be considered for selecting the suitable production technology. The powder compacting by explosion is a low cost and easy controllable technology, while the selection of right technological parameters requires large amount of practical knowledge. Regulator rods are made of powder material, like boron carbide powders, having neutron absorbing properties, which ability could be improved by compacting of these powders. Among the other technologies, explosive compacting is a possible method to meet this aim. In this paper the explosion compacting has been introduced; discussing in details the compacting methods of boron carbide powders, presenting the possible technological solutions, further the explosive compacting experiments. Properties of sample test pieces have been analysed, in order to prove applicability of explosive powder compacting technology.
\end{abstract}

Keywords: nuclear power plant, control rod, boron carbide, explosive powder compacting.

\section{Összefoglalás}

Az atomerőműi szabályzó rudak gyártására különböző megoldások alkalmazhatók. A kis darabszám miatti egyedi gyártás igen költséges lehet, így nem csak a megfelelő minőséget szolgáltató, de költséghatékonyságot eredményező technológiát kell választani. A robbantásos portömörítés egy olcsó és kézben tartható technológia, bár a technológiai paraméterek megválasztása számos gyakorlati ismeretet követel meg. A szabályozó rudak neutron elnyelő anyagból, például por formájú bórkarbidból készülnek, amelyet a neutron elnyelö képesség fokozása érdekében tömöríteni kell. A por tömörítésére, többek között, a robbantásos alakítás használható. A cikkben bemutatjuk a robbantásos portömörítési eljárást; részletesen ismertetjük a bórkarbid por tömörítésének technológiáit, bemutatjuk a lehetséges technológiai megoldásokat, az elvégzett robbantásos kísérleti alakításokat. Elemezzük a kísérletek során készült mintadarabok tulajdonságait, amelyek alapján bizonyítjuk a robbantásos portömörítési technológia alkalmazhatóságát.

Kulcsszavak: atomerömü, szabályzó rúd, bórkarbid, robbantásos portömörités. 


\section{Bevezetés}

A világon az atomenergia alkalmazása széles körben elterjedt, hazánk energiafelhasználásának közel 40\%-át atomerőmüben állítják elö. Napjainkban minden üzemben levő reaktor a hőt a maghasadásokból nyeri. A maghasadás során egy nehéz kémiai elem két kisebbre hasad, természetes, vagy mesterséges úton $\mathrm{Az}$ atommagot mesterségesen neutron befogással lehet hasítani. A maghasadás közben energia szabadul fel, a reakciótermékek mozgási energiájaként, illetve gamma-sugárzásként. Az urán esetében az atommag befog egy lassú (termikus) neutront, majd két kisebb magra bomlik, miközben 1-3 gyors neutron is felszabadul. Így a maghasadás több neutront kelt, mint amennyit elhasznál, az egész folyamat önfenntartó lesz, létrejön a láncreakció. A maghasadások számát, és ily módon a reaktor hö-teljesítményét szabályozni kell a biztonságos müködés érdekében:

- neutronelnyelö szabályzó rudakkal;

- moderátorba kevert bórsavval;

- moderátor mennyiségével;

- a tüzelőanyag elrendezésével.

$\mathrm{Az}$ atomerőmüvek biztonságos üzemeltetése jelentős kihívást jelent, ezért a szabályzó rúd a reaktorban létrejövő folyamatok kézbentartása szempontjából nélkülözhetetlen. A szabályzó rudak neutronelnyelő anyagból, például kadmiumból vagy bórkarbidból készülnek, melyek nagyobb valószínúséggel nyelik el a neutronokat, mint a hasadó elemek. A rudakat fel- és lemozgatják az aktív zónában. Amikor lejjebb süllyednek, több neutront nyelnek el, ezáltal csökken a maghasadások száma. A kihúzásuk esetén pedig nő a maghasadások száma, gyorsul a láncreakció. A veszélyhelyzetekben önmüködő szabályzó rudak szolgálják a balesetek elhárítását [1].

\section{A szabályzó rudak gyártásának módszerei}

A szabályzó rudak gyártására különböző megoldások alkalmazhatók, de a kis darabszám miatt az egyedi gyártás igen költséges lehet. Nem célszerü erre külön szerszámokat, célszerszámgépeket gyártani, mert nagyon megdrágítaná a szabályozó rúd gyártását. A megfelelő technológia kiválasztása gyártás szempontjából elengedhetetlen, hiszen a magas minőségi elvárások mellett, a költséghatékonyságot is szem előtt kell tartani. Napjainkban az atomerőmüi szabályzó rudak előállítása porkohászati úton történik. Ezt a módszert olyan feladatok teszik szükségessé, amelyek más, általánosan ismert eljárásokkal nem oldhatóak meg. Elöfordulhat azonban az is, hogy a porkohászati módszer alkalmazása nem kényszerítő szükségesség, de a jobb minőség és a gazdaságosabb gyártás érdekében mégis ezt használjuk. A porkohászat egy olyan technológiai eljárás, amely fél- és késztermékek, fém vagy egyéb porokból való gyártásával foglalkozik. A technológia alapfeladata a por alakú anyagrészecskék közötti érintkezés megnövelése. Ez két úton érhető el:

- a részecskék külső erők által történő deformálásával (sajtolással);

- az atomok érintkező felületén való összezsugorításával, ami nagy hömérsékleten az atomok megnövelt mozgékonysága révén jön létre (zsugorítás vagy szinterelés).

$\mathrm{Az}$ ismert porkohászati technológiák a fenti két eljárás különféle kombinációi. Az alakítás sebessége alapján osztályozva, statikus és dinamikus eljárásokat különböztetünk meg. A hagyományos porkohászat a statikus eljárások közé tartozik, melynek során a porokat illetve keverékeket üreges szerszámban a kívánt alakra sajtolják, majd az aránylag kis 
szilárdságú sajtolt munkadarabot védőgáz alatt hőkezelésnek vetik alá. A magas hömérséklet miatt fellépő diffúziós kölcsönhatás következtében kötés alakul ki a szemcsék között, melynek eredményeképpen egységes szilárd test keletkezik. Ezzel a technológiával elérhetö a kívánt minőség, de évente csak minimális számú szabályzó rúd gyártása szükséges, ami jelentős költségü. A különböző sajtolóés hőkezelő berendezések alkalmazása, nagymértékben drágítják az elóállitás folyamatát.

\section{A szabályzó rudak gyártása robbantásos portömörítéssel}

A készítendő alkatrész gyártásának másik lehetősége a robbantásos portömörítés, amely a dinamikus eljárások közé tartozik. Ezek az eljárások a porokat illetve porkeverékeket nagy energiájú nyomásimpulzussal tömörítik. Elsősorban olyan fém, kerámia, illetve keverék porok tömörítésére alkalmasak, melyek hagyományos porkohászati eljárásokkal nem vagy nehezen tömöríthetök [2]. A robbantásos portömörítés alkalmas technológia, különböző egyedi vagy kis sorozatú alkatrészek gyártására, mivel a technológia során nem szükséges drága szerszámokat gyártani, illetve a tömörítés energiaigényét is olcsó robbanóanyaggal biztosítani lehet. A kémiai robbanás eredményeként, nagysebességű reakció során, hirtelen nagy hő fejlődés mellett, nagymennyiségü gáz képződik. A magas hőmérsékleten a gázok kitágulnak, a levegöben lökéshullámot generálva. Ennek energiáját használjuk fel a fémalakító, megmunkáló robbantások során. A robbantásos fémmegmunkálási eljárások müszaki és gazdasági előnyeit akkor tudjuk kihasználni, ha speciális munkaterületeket alakítunk ki biztonságtechnikai és munkavédelmi szempontokat figyelembe véve. A robbantásos portömörítés napjainkban egy olcsó és kézben tartható technológia, meglehet a technológiai paraméterek megválasztása számos gyakorlati ismeretet követel meg.

\subsection{Tengelyszimmetrikus robbantásos portömörítés}

A nyomásimpulzus a hengeres tartályban elhelyezett tömörítendő por teljes külső felületére hat. A tartályt robbanóanyaggal kell körülvenni, ennek inicializálásával, $10^{8}-10^{11} \mathrm{~Pa}$ csúcsnyomású, nyomáshullám hozható létre. Ez a nyomáshullám egy „húzógyürüként”, a detonáció sebességével $(2000-7000 \mathrm{~m} / \mathrm{s})$ mozog a henger tengelyével párhuzamosan, a hengeres tartály anyagát képlékenyen alakítja, beszükíti, a benne lévő port tömöríti.

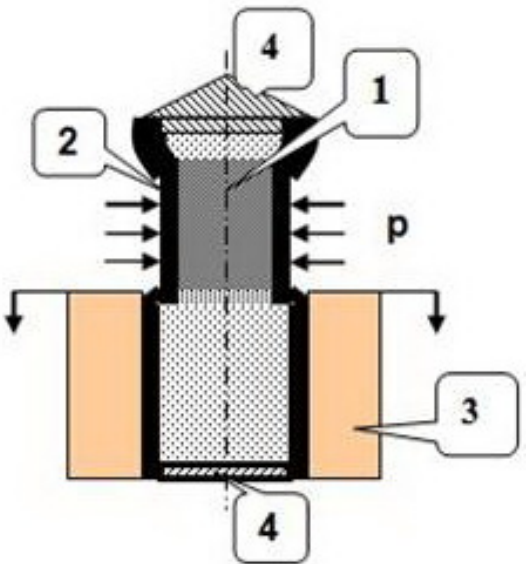

1. ábra. A tengelyszimmetrikus robbantásos portömörités vázlata:

1 -por, 2 - portartály (fémcsö),

3 - robbanóanyag, 4 - végzáró,

5 - elektromos gyutacs, $p$ - tömöritö nyomás

A robbantásos fémalakításnál a nyomás nagyságát a megfelelő detonációsebességü robbanóanyag kiválasztásával lehet befolyásolni. A robbanás által létrejövő nagy nyomás néhány mikro-szekundumig hat, de ez a nyomás nagyságrendekkel 
nagyobb, mint a fém statikus terhelésekor alkalmazható nyomófeszültség. A nagy detonációsebességgel terjedő nyomásimpulzus hatására, a fémfelületen kialakuló feszültségek, ennek a sebességnek a nagyságától függően, különböző módon terjedhetnek a céltárgy belseje felé. Ha a detonációsebesség nem éri el a hangsebességet, akkor a felületen képlékeny alakváltozás jön létre, ami elnyeli a robbanás során a fémmel közölt energia egy részét. Ez az alakváltozás csak bizonyos mértékig terjed a fém belseje felé, az elérhető alakváltozás mértéke a detonáció helyétől távolodva jelentősen csökken. Amennyiben a detonációsebesség meghaladja a hangsebességet, nem alakul ki képlékeny alakváltozás. A fémben ilyenkor fellépő erősen lokalizált, rugalmas lökéshullámok a test valamely részén, a többi folyamatoktól teljesen függetlenül hatnak. Ezek a hullámok lassan csillapodnak, és a fém megrongálódásához vezetnek.

\subsection{Robbanózsinóros portömörítés}

A modellkísérletek során több, különböző méretü rudat készítettünk, majd vizsgáltuk méret és alak megfelelőség szempontjából. Több kísérlet elvégzése után arra a következtetésre jutottunk, hogy a robbantás eredménye robbanózsinór alkalmazásával jobb lesz. A robbantás során keltett sokkhatás következtében, a cső alakítása egyenletes mértékü lett, körkörös, megfelelő méretű rudat kaptunk. A robbanózsinór detonációsebessége sokkal nagyobb, mint a korábbi kísérletek során alkalmazott ammónium-nitráté, viszont a robbantás folyamata sokkal könnyebben szabályozható.

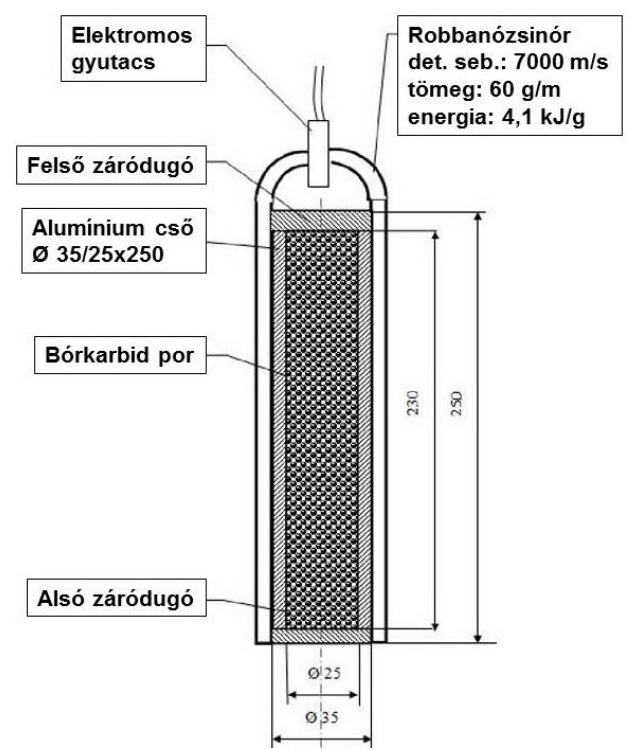

2. ábra. A robbanózsinóros portömörités vázlata

\section{Következtetések}

Kísérleteink igazolták, hogy egy olcsó és egyszerü technológia kidolgozásával, költséghatékonyabbá tehető a szabályzó rudak gyártása.

A robbanózsinór alkalmazása célszerübb a szabályzó rúd gyártásához, annak ellenére, hogy a detonációsebessége nagyobb, mint a robbanóporé. Feltehetö, hogy a robbanás kinetikája ad erre magyarázatot.

\section{Szakirodalmi hivatkozások}

[1] MVM Paksi Atomerőmü Zrt. 7031 Paksm Pf.71. www.atomeromu.hu (2014/10)

[2] Göbl, N., Horváth, D., Kovács-Coskun, T., Lukács, L., Rácz, P., Szalay, A., Zádor, I.: Nagyenergiájú Fémmegmunkálás, Nemzeti Közszolgálati Egyetem, Budapest, 2013, 226. 